\title{
Anticancer and antioxidant activity of ethanolic extract of Clove (Syzygium aromaticum) on oral squamous cell carcinoma cell lines (KB cell lines)- An In-vitro study
}

\author{
Research Article
}

\section{Sheethal Sanikop ${ }^{*}$, Kishore Bhat ${ }^{2}$, Vijayalakshmi Kotrashetti ${ }^{3}$, Vijay Kumbar ${ }^{4}$, Renuka Ammanagi5, Peram MR6}

\begin{abstract}
1. Professor, Department of Periodontology, 2. Professor and Head, Department of Microbiology, 3. Professor and Head, Department of Oral Pathology and Microbiology, 4. Research officer, Central Research Laborartory, 5. Professor and Head, Department of Oral Medicine and Radiology, 6. Associate Professor, Central Research Laboratory, Maratha Mandal's Nathajirao G. Halgekar Institute of Dental College and Research centre, Belgaum.
\end{abstract}

\begin{abstract}
Cloves (Syzygium aromaticum) as been used as traditional medicine for many years and they possess antibacterial, antifungal and antiviral properties. Clove is known for its anticancer property on various cancer cell lines and is well established, but its anticancer effect on OSCC cell lines is less known. Aim of the study was to determine the anticancer and antioxidant effect of Syzygium aromaticum extract on OSCC cell lines (KB cell lines) and compare the same with normal mouse fibroblasts cell lines (L292 cell lines). KB cell lines and L292 cell lines were commercially obtained. Clove was obtained from local market and ethanolic extract (EC) of clove was prepared. Anticancer activity was assessed by MTT, neutral red, DAPI and Double staining assay and antioxidant assay was carried out by FRAP, PM and DPPH assay. The antioxidant property of EC of clove increased with increase in the concentration in a dose dependent manner. Both MTT and Neutral Red assay showed increase in cell death with increase in concentration of EC of clove. Double staining and DAPI showed increase in cell death when treated with EC of clove. The anticancer and antioxidant activity of EC of clove was comparable with standard drug used in the assay. This in vitro study demonstrates effective anticancer and antioxidant activity on KB cell lines when compared to standard control. However, further studies are to be conducted in order to characterize other potential antitumor components of the clove, so that it can be used as therapeutic agent in treating oral carcinoma.
\end{abstract}

Key Words: Syzygium aromaticum, Clove, Ethanolic extract, Anticancer activity, KB cell lines.

\section{Introduction}

Cancer is a major public health problem in the world with its statistical numbers continuing to increase (1). Oral cancer falls in the top three of all cancers in India and is estimated that over $30 \%$ of all cancers reported in the country are oral cancers. The incidence of oral cancer is highest in India, South and South East Asian countries. Currently, therapies for oral cancer are surgical treatment, hormone therapy, radiation therapy, and chemotherapy. These treatment options results with adverse and toxic side effects (2). The exploration of medicinal plants continues to hold significant promise for the prevention and treatment of cancer with minimal or no side effects. Evidence from World Health Organization states that about $65 \%$ of the population across the globe prefer to use traditional or herbal

* Corresponding Author:

Sheethal Sanikop

Professor, Department of Periodontology

Maratha Mandal's Nathajirao G. Halgekar Institute of

Dental College and Research centre

Belgaum-590010, Karnataka. India

Email Id: sanikopsheetal@,gmail.com medicine to treat diseases (3). It is stated that up to 30 $40 \%$ of anticancer drugs used worldwide are derived from plant sources (1). The use of complementary alternative medicines has dramatically increased in India along with USA, in the last two decades. Medicinal plants and other natural resources comprise of approximately $60 \%$ of anticancer agents and many more natural plants have an anticancer potential but they have not yet been fully investigated (3). Natural products have played an important role as an effective source of antitumor agents (1). Clove is one of the natural products which is not only used as a flavoring agent in food products and also as a fragrant in cosmetics. Apart from this it is also been widely used in traditional medicine in many Asian countries as an antiseptic, analgesic or antibacterial agent (2).

Clove is derived from flower buds of the Eugenia caryophyllata tree, a native to Indonesia. Scientifically clove is known as Syzygium aromaticum (L) which belongs to family of Myrtaceae. It is an aromatic spice, cultivated in India, Madagascar, Sri Lanka, Indonesia, South of China and some part of Africa. The common uses of clove have been attributed to some of its biological activities such as antibacterial, 
antifungal, insecticidal and antioxidant properties $(4,5,6)$.

Eugenol is an important component which can be separated from the oil extract of clove bud, has shown to have many pharmacological functions such as anticancer and antibacterial effect. Apart from eugenol several other bioactive components found in clove are tannins, terpenoids, eugenol, and acetyleugenol (7), which are also known to possess antiseptic, antibacterial, antifungal, and antiviral properties (8.9).

Clove contains high amounts of eugenol, which is an allyl chain-substituted guaiacol, may be responsible, at least in part, for the induction of the phase II enzymes and/or serve as an antioxidant. In a study, eugenol decreased the viability of two breast cancer cells that is estrogen positive $\mathrm{MCF}-7$ and estrogen negative MDA-MB-231 cells in a concentration dependent manner with $\mathrm{MCF}-7$ being more sensitive (2).

The antiproliferative activity of eugenol against melanoma, leukemia, gastric, skin tumor and prostate cancer cells has been confirmed by much research, and Eugenol can induce apoptosis in various cancer cells such as mast cells, melanoma cells and HL-60 leukemia cells (10).

Considering its anticancer activity we did literature search to find out anticancer effect of clove on Oral squamous cell carcinoma (OSCC) cell line and we found lack of studies on effect of Syzygium aromaticum on OSCC cell lines, hence an in vitro study was designed to determine the effect of Syzygium aromaticum extract on OSCC cell lines (KB cell lines).

\section{Materials and Methods}

OSCC cell lines (KB cell lines) and normal mouse fibroblasts (L292 cell lines) cell lines were procured from NCCS, Pune, which was stored in DMEM with low glucose (Cat No-11965-092).

\section{Preparation of Clove extract}

The shade dried cloves were procured from the local market. The obtained cloves were finely powdered and mixed with absolute ethanol at room temperature for $48 \mathrm{hr}$. After filtration, the solution was concentrated under vacuum and dried at room temperature to get the dry residue. The residue was suspended in distilled water and further extracted with ethyl acetate to obtain the crude extract (1). The extract was stored in powder form and refrigerated at $4^{\circ} \mathrm{C}$ till further use.

\section{Determination of antioxidant activity by using in vitro methods}

Ferric ion reducing antioxidant power assay (FRAP)

This method helps us to measure the total antioxidant power of the extracts. The Benzie and Strain method with slight modification was used to perform the antioxidant activity assays. Ethanolic extract of Syzygium aromaticum were mixed in different concentrations ranging from $100 \mu \mathrm{g}$ to $200 \mu \mathrm{g}$ with 2.5 $\mathrm{mL}$ of $0.2 \mathrm{mM}$ phosphate buffer $(\mathrm{pH} 7.4)$ and $2.5 \mathrm{~mL}$ of potassium ferricyanide ( $1 \%$ weight/volume $(\mathrm{W} / \mathrm{V}))$. The obtained mixture was subjected to incubation at $50^{\circ} \mathrm{C}$ for 20 minutes, followed by addition of $2.5 \mathrm{~mL}$ of trichloroacetic acid $(10 \% \mathrm{~W} / \mathrm{V})$ and centrifuged at $3000 \mathrm{rpm}$ for 10 minutes. Then, $2.5 \mathrm{~mL}$ of distilled water was added and later $0.5 \mathrm{~mL}$ of ferrous chloride $(0.1 \%$ $\mathrm{W} / \mathrm{V})$. In the end, the absorbance was measured at 700 $\mathrm{nm}$ using spectrometry. The positive reference standard used was ascorbic acid (3). Each assay was repeated twice.

\section{Phosphomolybdenum assay}

Phospho-molybdenum (PM) assay was carried out using the standard procedure of Prieto et al to estimate the total antioxidant activity. In the test tube containing $3 \mathrm{~mL}$ of distilled water and $1 \mathrm{~mL}$ of molybdate reagent solution, ethanol extract of Syzygium aromaticum in a different concentration ranging from $100 \mu \mathrm{g}$ to $200 \mu \mathrm{g}$ were added. Incubation of these test tubes was done at $95^{\circ} \mathrm{C}$ for 90 minutes. The test tubes were kept at room temperature for 20-30 minutes after incubation. The absorbance was measured at $695 \mathrm{~nm}$ using ascorbic acid as the reference standard (3). Each assay was repeated twice.

\section{2, 2-Diphenyl-1-picrylhydrazyl radical scavenging ability assay}

The stable scavenger 2, 2-diphenyl-1picrylhydrazyl (DPPH) with slight modifications as described by Brand-Williams et al method was used to determine the free radical scavenging effect of Syzygium aromaticum bud extract. The ethanolic extract of Syzygium aromaticum in a different concentration ranging from $100 \mu \mathrm{L}$ to $200 \mu \mathrm{L}$ was added. DPPH solution $(0.004 \%)$ was prepared in ethanol and $1 \mathrm{ml}$ of this solution was separately mixed with the same volume of ethanol clove extracts and standard ascorbic acid solution and 30 minutes of incubation of the mixture was done and then the mixture was again incubated in the dark at room temperature. After which, the absorbance was measured at $517 \mathrm{~nm}$. The scavenging efficiency of the extract was indicated by the degree of DPPH purple depolarization to DPPH yellow. Lower absorbance of the reaction mixture indicated higher free radical-scavenging activity. The following equation was used to calculate the scavenging activity against DPPH;

DPPH scavenging activity $(\%)=\mathrm{Ac}-\mathrm{At} /$

Ac $\times 100$

Where Ac is the absorbance of the control reaction (1 $\mathrm{ml}$ of ethanol with $1 \mathrm{ml}$ of DPPH solution), and At is the absorbance of the test sample. The results were analyzed in triplicate. $50 \%$ of the DPPH free radical will be inhibited by the $\mathrm{IC}_{50}$ value is the concentration of sample (3). Each assay was repeated twice.

\section{Cytotoxicity assay}

Methyl Tetrazolium (MTT) Assay:

A density of approximately $5 \times 10^{3}$ cells/well in a 96-well flat-bottom micro plate was used to seed the cells and the cells were kept overnight at $37^{\circ} \mathrm{C}$ in $95 \%$ humidity and $5 \% \mathrm{CO}_{2}$. Different concentrations $(25,50$, $100,200,400$ and $800 \mu \mathrm{g} / \mathrm{ml}$ ) of samples were treated and then the cells were incubated for another 48 hours. 
The cells in the well were washed twice with phosphate buffer solution. $20 \mu \mathrm{L}$ of the MTT staining solution $(5 \mathrm{mg} / \mathrm{ml}$ in phosphate buffer solution) was added to each well and plate was incubated at $37^{\circ} \mathrm{C}$. After $4 \mathrm{~h}$, $100 \mu \mathrm{L}$ of dimethyl sulfoxide (DMSO) was added to each well to dissolve the formazan crystals, and absorbance was recorded with a $570 \mathrm{~nm}$ using microplate reader $(1,2)$. Each assay was repeated three times.

Formula: Surviving cells $(\%)=$ Mean Optical density (OD) of test compound /Mean OD of Negative control $\times 100$

Using graph Pad Prism Version 5.1, we calculate the IC 50 of compounds

\section{Neutral Red Uptake Assay}

Approximately $5 \times 10^{4}$ cells were seeded per well in 96-well plates and DMEM containing 5\% FBS was added and allowed to attach overnight. Different concentrations $(25,50,100,200,400$ and $800 \mu \mathrm{g} / \mathrm{ml})$ of samples were treated by diluting using DMEM media and incubated for 48hours. After the incubation period, the media was removed to which $100 \mathrm{ml}$ of neutral red medium was added to each well of the plate. The plate was incubated for $2 \mathrm{~h}$ at appropriate culture conditions. Later the neutral red medium was removed and the wells were washed with PBS. $150 \mathrm{ml}$ neutral red destain solution was added per well. The plates were shaken rapidly on a micro titer plate shaker for at least $10 \mathrm{~min}$, or until the neutral red has been extracted from the cells and has formed a homogeneous solution. OD value of neutral red extract was measured at $540 \mathrm{~nm}$ in a micro liter plate reader spectrophotometer, using blanks which contain no cells (11). Each assay was repeated three times.

\section{Anticancer activity \\ Double staining (Acridine orange/ Ethidium bromide)}

The cells were seeded in a 24-well flat-bottom microplate containing cover slips and maintained at $37^{\circ} \mathrm{C}$ in $\mathrm{CO}_{2}$ incubator for overnight. $\mathrm{IC}_{50}$ value of the compound was treated at $48 \mathrm{hrs}$. After the incubation, cells were washed with PBS and fixed with $4 \%$ paraformaldehyde for $30 \mathrm{~min}$. $20 \mu \mathrm{L}$ of dye mixture (Acridine orange and ETBR) was incubated for $5 \mathrm{~min}$ at room temperature in the dark and examined under fluorescent microscope at $40 \mathrm{X}$ magnification. (Microscope Olympus BX41) 10 fields were randomly checked for live and dead cells and were counted (12).

\section{DAPI:}

The cells were seeded in a 24-well flat-bottom microplate containing cover slips and maintained at $37{ }^{\circ} \mathrm{C}$ in $\mathrm{CO}_{2}$ incubator for overnight. $\mathrm{IC}_{50}$ value of the compounds was treated at $48 \mathrm{hrs}$. After the incubation, cells were washed with PBS and fixed with 4\% paraformaldehyde for $30 \mathrm{~min}$. $20 \mu \mathrm{L}$ of DAPI was incubated for $5 \mathrm{~min}$ at room temperature in the dark, examined under a fluorescent microscope (Microscope Olympus BX41). Randomly selecting the fields in the microscope and number of cells were counted which had undergone apoptosis. Then percentage of apoptotic cells were calculated (12).

\section{Results}

Determination of antioxidant activity by using in vitro methods:

Ferric ion reducing antioxidant power (FRAP) assay:

The presence of antioxidants in the sample would result in the reduction of ferri cyanide $\mathrm{Fe} 3+$ to ferro cyanide $\mathrm{Fe} 2+$ by donating an electron. $\mathrm{EC}$ of clove was subjected to FRAP assay along with standard ascorbic acid. In the results obtained showed antioxidant activity which was comparable with that of standard ascorbic acid. The antioxidant property increased with increase in the concentration of EC of clove in a dose dependent manner (Table 2, Graph 1).

\section{Phosphomolybdenum (PM) assay}

In the present study, EC of clove were subjected to PM assay along with standard ascorbic acid. Ethanolic extract showed antioxidant activity which was comparable to standard ascorbic acid in dose dependent manner (Table 3, Graph 2).

\section{2,2-Diphenyl-1-picrylhydrazyl radical scavenging ability (DPPH) assay}

In the present study, the different concentrations of EC of cloves were subjected to DPPH free radical scavenging assay. The antioxidant capacity of the extract was comparable to standard ascorbic acid (Table 4).

\section{Cytotoxicity assay MTT Assay}

IC50 value was calculated for MTT assay which is shown in table 1a

The comparison of cytotoxicity of Syzygium aromaticum extract towards the human squamous cell carcinoma cell line (KB cell lines) against the cytotoxicity of cisplatin was done by MTT assay. The complex induces a cytotoxic effect in a concentrationdependent manner. The $\mathrm{IC}_{50}$ value of Syzygium aromaticum extract against the $\mathrm{KB}$ cell line was $224.3 \mu \mathrm{g} / \mathrm{ml}$ and that of cisplatin was $2.785 \mu \mathrm{g} / \mathrm{ml}$ under identical experimental conditions. Clove extract showed highly significant activity at 50, 100, 200, 400 and $800 \mu \mathrm{g}$. Maximum activity was seen at $800 \mu \mathrm{g}$. For the purpose of evaluation of the cytotoxic effects of the ethanolic extract of Clove, KB cell lines were treated with specified concentrations of the extract for $48 \mathrm{~h}$. Cisplatin was used as a positive control. Extract of clove was treated with MTT at different concentration and maximum significant death was found at $800 \mu \mathrm{g} / \mathrm{ml}$ as compared to low concentration. Very less amount of viable cells were detected at this concentration which showed maximum inhibition at this concentration. While decreasing the concentration of clove extract the viability of the cell showed negligible amount of cell death and minimum lethal dose (Table 5a, 5b). 


\section{Neutral Red Assay}

IC50 value was calculated for MTT assay which is shown in table $1 \mathrm{~b}$

The result of Neutral Red assays revealed that the ethanol extract of Syzygium aromaticum decreased the viability of all the cancer cell line. Ethanol extract of Syzygium aromaticum was found to induce more cytotoxicity towards cancer cell lines (KB) as compared to Normal fibroblast (L292) cell lines(486). That is, the extract showed no or negligible cytotoxic effect towards non cancerous normal fibroblast (L292) cell line. The effect induced by the extract was also comparable with that of the standard chemotherapeutic drugs such as Cisplatin (CP). There was increase in cell death with increase in concentration of EC of clove. These results revealed morphological changes and shrinkage of cells leading to cell death induced by the extracts in the KB cell lines (Table 6a,6b).

\section{Anticancer activity \\ Double Staining}

Double staining includes the use of a mixture of two highly fluorescent dyes and acridine orange (AO) penetrates the living cells with intact cell membranes producing an intense uniform green fluorescence. In contrast, ethidium bromide (EB) can enter only the dead cells with the damaged cell membranes emitting a bright orange/red fluorescence (13). The cells in untreated and treated groups seemed green in color with uniform intensity while cells treated with Syzygium aromaticum and cis platin showed a dark orange-red color suggesting significant cell death. The cell death may be due to the action of Syzygium aromaticum that disrupts the cell plasma membrane at the end of the treatment period (Figure 1).

\section{DAPI staining}

The apoptotic nuclear morphology changes in KB cells following the treatment with Syzygium aromaticum for 48 hours when observed using DAPI staining. The untreated cells displayed normal intact nuclei with weak homogenous blue staining whereas, in the groups treated with Syzygium aromaticum showed small nuclei with bright chromatin condensation, blebbing, nuclear fragmentation and apoptotic bodies (small spherical fragments) formation. The results indicate that Syzygium aromaticum induce apoptosis in $\mathrm{KB}$ cells compared with both the control and Cisplatin treated cells (Figure 2).

\section{Discussion}

Clove (Syzygium aromaticum) is one of the most commonly used spices in Indian kitchens. It has been shown to be a potent chemo preventive agent, used by the traditional Ayurvedic healers of India since ancient times to treat respiratory and digestive ailments (14). Essential oils present in the dried flower buds of clove are eugenol, caryophyllene, alpha-humulene, alphaterpinyl acetate, eugenyl, methyl eugenol, acetyl eugenol, naphthalene, chavicol, heptanone, sesquiterpenes, methyl salicylate pinene, vanillin (15). The major chemical constituents of clove include sesquiterpenes, volatile oil (eugenol), caryophyllene, tannins and gum. Among different essential oils eugenol is the principle component, present in amount of $81.1 \%$. Beside this trans-cryophyllene and isoeugenol are present in amount of $7 \%$ and $10.1 \%$ respectively (16). The main compound of clove is eugenol which is used as an antiseptic, antibacterial, analgesic agent in traditional medical practices. Now it is used in pharmaceutical and food products and in beverages as a flavoring agent. The therapeutic benefits of eugenol are well known. In recent times, it has been studied for a variety of promising biological properties. It has been reported to participate in photochemical reactions and to possess insecticidal, antioxidant and anti-inflammatory activities (17). Studies have shown that clove has antiviral properties and have inhibitory effect on viruses like Herpes Simplex Virus (HSV) and hepatitis C virus (HCV) $(18,19)$.

In the recent years clove has been studied extensively for various cancers like breast cancer, prostate cancer, cervical cancer, esophageal cancer and leukemia cell lines etc to check the anticancer activity (20). In vitro studies on OSCC cell lines to check the efficacy of clove extract is lacking thus the present study aimed to check the anticancer effect of ethanolic clove extract on OSCC cell lines.

In the present study cytotoxic effect was analyzed by MTT, neutral red uptake assay and apoptosis by double staining and DAPI. The MTT and neutral red assay results showed growth inhibition in KB cell lines when subjected with ethanolic clove extract. The effect was more with increase in the concentration of the extract and it was comparable with standard drug. The extract had effect on normal cell lines at a very higher concentration and the effect was minimal.

The MTT assay is used in screening the crude extracts as well as in the isolated compounds to assess the toxicity. It also provides an indication of possible cytotoxic properties of the tested plant extracts. MTT assay is based on the reduction of MTT by mitochondrial dehydrogenase by purple formazan product. It is frequently used as an in vitro model system to measure cytotoxic effects of variety of toxic substances and plant extracts against cancer cell lines. In vitro cytotoxicity test using L 292 and KB cancer cell lines was performed to screen potentially toxic compounds that affect basic cellular functions and morphology. The effect was observed at varied concentration in a time dependent manner. The concentration of each extract was evaluated in triplicates by serial dilution. The results showed that ethanol extract significantly inhibited the (KB) cell lines and was the most potent extract with IC50 value at $224.3 \mu \mathrm{g} / \mathrm{ml}$ for $\mathrm{KB}$ cell lines and for L292 cell line it was $607.8 \mu \mathrm{g} / \mathrm{ml}$. The results also confirmed the differential effect induced by the extracts and standard drug in cancerous and normal cells. Therefore, the inhibition of cell growth by Syzgium aromaticum extracts might be due to the power of the solvent in surpassing effect of several bioactive constituents, the presences of phenolic compounds like gallic acid and 
other antioxidant agents that are present in Syzgium aromaticum.

Similar observations was made with neutral red assay were the cytotoxic effect on $\mathrm{KB}$ cell lines was observed in a dose dependent manner and the inhibition of cell growth was observed with higher concentration of EC and the results obtained was comparable with standard drug.

Apoptosis is an important phenomenon in cancer chemotherapy, because anticancer drugs exert their antitumor effect against cancer cells by inducing apoptosis (21). Therefore, it is hypothesized that eugenol may exert its cytotoxic activity on different cancer cells by inducing apoptosis. In this study, we tested this hypothesis and found that the cytotoxic effect of eugenol is associated with apoptosis. In view of these finding we performed DAPI and double staining and observed that cell shrinkage was seen in clove extract treated cells, a major characteristics of nuclear fragmentation due to which the cells were seen dying in comparison to untreated control cells. DAPI staining demonstrated that clove extract induced change in nuclear morphology. Compared to the typical round nuclei of the control, treated cells displayed condensed and fragmented nuclei. It was observed that level of apoptotic cell was comparable with standard control. Further our findings correlated with the findings of Pisano et al. (2007) in their study they showed eugenol treated melanoma cells exhibits cytotoxic activity induced by apoptosis (22). In the present study we found similar result, also when double staining was done to distinguish between live and dead cell significant amount of cell death was observed in cancer cell line treated with ethanolic extract and was comparable with standard drug used as control. DAPI or Double staining showed results which are in accordance with the study done by Bhat et al (2018) (23).

Finding of our study results was in accordance with the study done by Dwivedi $\mathrm{V}$ et al (2011) using three different extract of clove on different cell lines using MTT assay and DAPI. They found significant cell growth inhibition in dose dependent manner in oesophageal cancer cell lines where as it was not significant in prostste cancer. Oil extract was better than aqueous and ethanolic extract with respect to cytotoxic effect on cell lines (19). Study done by Arunava D et al., to evaluate the therapeutic potential of eugenol showed cell viability in time and dose dependent manner with consistent morphological changes. Flow cytometry determined apoptosis confirming the cytotoxicity value for MTT at IC50 with $81.85 \%$ cell viability (24).

Study done by $M$ Joyce Nirmala to check anticancer activity on thyroid cancer cell lines using MTT assay and also to check for apoptosis they performed Annexin V-FITC assay and found the clove oil emulsion showed inhibition of cell growth and also apoptosis. along with apoptosis, even necrosis was checked by staining with propidium iodide which showed presence of necrosis in cancer cell lines whereas the normal cell lines were not affected (25). This finding is similar to our study.
A study done to check cytotoixc effect of ethanolic clove extract along with FMSP-nanoparticles, they performed tryphan blue assay, DAPI and MTT on breast cancer cell lines. They demonstrated that cancer cell viability was decreased to $55.40 \%$ when treated with FMSP-nanoparticles alone, whereas when cancer cells were treated with FMSP-nanoparticles along with crude clove extracts, the cell viability drastically decreased to $8.50 \%$. Both morphological and quantitative data suggest that the combination of FMSPnanoparticles plus crude clove extracts are more effective in treating cancer cells and they suggested that combination treatment of nanoparticles along with clove extracts hold a great promise for the cancer treatments (26). However in our study plain extract showed good cytotoxic effect on KB cell lines without adding any nanoparticles.

Followed by cytotoxic assay we further studied antioxidant activity by using invitro methods like FRAP, PM, and DPPH. In this study, the total antioxidant capacity of ethanol extract of clove was evaluated.

DPPH is stable nitrogen centered free radical which is conventionally used to determined free radical scavenging activities of antioxidants present in plant extract or synthetic compound. The reduction capability of DPPH radical is determined by the decrease in absorbance at $517 \mathrm{~nm}$ induced by the antioxidant. In the present study, the antioxidant activity of Syzygium aromaticum was evaluated using methanol, ethanol, and aqueous extract of the plant and was compared with standard ascorbic acid. In this study, the total antioxidant capacity of ethanol extracts were evaluated by three methods that is FRAP, PM, and DPPH. The ferric ion-reducing antioxidant power assay of the extract may serve as a significant indicator of its potential antioxidant activity. The presence of antioxidants, which have been shown to be an impart antioxidant action by breaking the free radical chain by donating a hydrogen molecule. The presence of antioxidants in the extract would result in the reduction of ferri cyanide(Fe3+) to ferro cyanide( $\mathrm{Fe} 2+)$ by donating an electron which was measured spectrophotometrically at $700 \mathrm{~nm}$. In this assay, the yellow color of the test solution changes to various shades of green and blue, depending on the reducing power of plant extract. The reducing power increased with the increase in the extract concentrations. This may be served as significant indicator of its potential antioxidant activity. Hence, this study presumed that the methanol extract of Syzygium aromaticum may have a high amount of antioxidant properties which was comparable to that of the synthetic antioxidant standard used.

The total antioxidant activity of the sample was analyzed by the PM method. It is calorimetric quantitative method which measures the reduction of Phosphate-Mo (VI) to Phosphate-Mo (V) by the sample and subsequent formation of a bluish green colored Phosphate-Mo (V) complex. It helps to examine the reduction rate among the antioxidant and molybdenum 
ligand. In the present study methanol extract exhibited higher absorbance than ethanol and aqueous extract.

The study done by Faisal Nur Alfikri et al (2020) to determine the antioxidant property of Clove bud oil at the different phenological stages in young and mature trees. The study showed percentages of DPPH radical inhibition by oil at three concentrations. Interactions between tree age, phenological stage, and oil concentration for antioxidant activity were significant. The flowering stage extract of young trees at a concentration of $45 \mu \mathrm{g} / \mathrm{mL}(67.65 \%)$ had the highest antioxidant activity. In mature trees, the extract of bud at flowering stage at a concentration of $45 \mu \mathrm{g} / \mathrm{mL}$ $(64.29 \%)$ had the highest antioxidant activity. In general, young trees have antioxidant activity greater than mature ones. The antioxidant activity increased with the budding stage. Best quality of clove essential oil was obtained from buds of mature trees at flowering stage, while those of young trees had the strongest antioxidant activity (27). These results of the present study are similar to the results observed by Meryem Bakour et al., (28).

The DPPH scavenging capacity of the clove essential oil at the concentration of $484.7 \mu \mathrm{g} \mathrm{mL}-1$ was $94.86 \%$. A lower inhibition of $28.83 \%$ and $22.13 \%$ was observed for hydroxyl and nitric oxide radicals, respectively, for the essential oil concentration of 12.25 $\mu \mathrm{g} \mathrm{mL}-1$. The high DPPH scavenging activity observed for the clove essential oil can be explained by a synergistic effect between phenolic compounds, even at low concentrations. In contrast, the lower inhibition values obtained for hydroxyl and nitric oxide radicals may be due to the low interaction of the phenolic compounds with these radicals. A stronger DPPH scavenging activity was found for the clove essential oil under study compared to the results reported in the literature. For instance, Silvestri et al.(2010) reported $45.27 \%$ of scavenging, at the concentration level of 500 $\mu \mathrm{g} \mathrm{mL}-1(29)$, while $92.82 \%$ was reported by Sebaaly et al. (2016) at the concentration level of $10000 \mu \mathrm{g}$ $\mathrm{mL}-1(30)$.

The antioxidant activity of clove and caraway were screened using various in vitro models, such as bcarotene-linoleate, ferric thiocyanate, 1,1-diphenyl-2picryl hydroxyl (DPPH) radical, hydroxyl radical and reducing power model systems concluding that the antioxidant activity of clove and caraway is comparable with butylated hydroxytoluene (BHT), a synthetic compound commonly employed as food preservative. According to Gülçin, the antioxidant activity of clove oil compared with synthetic antioxidants measured as the scavenging of the DPPH radical decreased in the following order: clove oil $>$ BHT $>$ alfatocopherol $>$ butylated hydroxyanisole $>$ Trolox.

The antioxidant activity of aqueous extracts of clove has been tested by different in vitro methods as 2,2-diphenyl-1-picrylhydrazyl (DPPH); 2,2'-azino-bis (3-ethylbenzothiazoline-6-sulphonic acid) (ABTS), oxygen radical absorbance capacity, ferric reducing antioxidant power, xanthine oxidase and 2deoxiguanosine. Clove and plants as pine, cinnamon, and mate proved its enormous potential as food preservative among the other 30 plants analyze.

Ethanol and aqueous extracts of clove and lavender at concentrations of 20,40 and $60 \mu \mathrm{g} / \mathrm{mL}$ showed inhibitions up to $95 \%$ when tested as metal quelants, superoxide radical capture and scavenging of the DPPH radical. The powerful antioxidant activity of both extracts may be attributed to the strong hydrogen donating ability, metal chelating ability and scavanging of free radicals, hydrogen peroxide and superoxide (31).

All the above study findings are similar to our study where we found antioxidant effect through DPPH, PM and FRAP in a dose dependent manner and the effect increased with increase in the concentration.

\section{Conclusion}

In conclusion the present study result demonstrated clove has a potent anticancer property. Ethanolic clove extract is an effective cytotoxic agent for $\mathrm{KB}$ cell lines and also has a capability of inducing apoptosis in KB cell lines. The study also showed ethanolic extract of clove also as good antioxidant property in KB cell lines. This invitro study demonstrates the applicability of clove has a novel therapeutic herb for treatment of OSCC. This is a preliminary study done to demonstrate anticancer and antioxidant property of clove. Further studies are to be conducted in order to characterize other potential antitumor components of the clove and confirmatory tests are to be conducted through in vivo studies and clinical trials.

\section{References}

1. Liu. H, Schmitz J. C, Wei J, Cao S, Beumer J. H, Strychor S., Cheng L, Liu M. W, Wu C. N, Zhao X, Zhang Y, Liao J, Chu E, Lin X. (2014). Clove extract inhibits tumor growth and promotes cell cycle arrest and apoptosis. Oncology research, 2014;21(5): 247-259.

2. Al Wafai R, El-Rabih W, Katerji M, Safi R, El Sabban M, El-Rifai O, Usta J. Chemosensitivity of MCF-7 cells to eugenol: release of cytochrome-c and lactate dehydrogenase. Sci Rep. 2017 (8);7:43730.

3. Ghagane S. C, Puranik S. I, Kumbar V. M, Nerli R. B, Jalalpure S.S, Hiremath M.B, Neelagund S, Aladakatti R. In vitro antioxidant and anticancer activity of Leea indica leaf extracts on human prostate cancer cell lines. Integr Med Res. 2017;6(1):79-87.

4. Lee KG, Takayuki S. Antioxidant property of aroma extract isolated from clove buds [Syzygium aromaticum (L.) Merr. Et Perry], Food Chemistry. 2001;74(4):443-448.

5. Huang Y, Ho S.H, Lee H.C, Yap Y.L. Insecticidal properties of eugenol, isoeugenol and methyleugenol and their effects on nutrition of Sitophilus zeamais Motsch. J. Stored Prod. Research. 2002;38:403-412..

6. Velluti A, Sanchis V, Ramos A, Turon C, Marín S. Impact of essential oils on growth rate, zearalenone 
and deoxynivalenol production by Fusarium graminearum under different temperature and water activity conditions in maize grain. J. of Applied Microbiol. 2004;96:716-724.

7. Kluth D, Banning A, Paur I, Blomhoff R, BrigeliusFlohé R. Modulation of pregnane X receptor- and electrophile responsive element-mediated gene expression by dietary polyphenolic compounds. Free Radic Biol Med. 2007 ;42(3):315-25.

8. Kaefer C. M, Milner J. A. Herbs and Spices in Cancer Prevention and Treatment. In: Benzie IFF, Wachtel-Galor S, Editors. Herbal Medicine: Biomolecular and Clinical Aspects. 2nd edition. Boca Raton (FL): CRC Press/Taylor \& Francis; 2011. Chapter 17.

9. Md. Nazrul Islam Bhuiyan, Jaripa Begum , Nemai Chandra Nandi and Farhana Akter, Constituents of the essential oil from leaves and buds of clove (Syzigium caryophyllatum (L.) Alston), African Journal of Plant Science.2010;4(11): 451-454

10. Ma M, Ma Y, Zhang G. J, Liao R, Jiang X. F, Yan X. X, Bie F. J, Li X. B, Lv Y. H. Eugenol alleviated breast precancerous lesions through HER2/PI3KAKT pathway-induced cell apoptosis and S-phase arrest. Oncotarget. 2017;8(34):56296-56310.

11. Repetto G, del Peso A, Zurita JL. Neutral red uptake assay for the estimation of cell viability/ cytotoxicity. Nat Protoc. 2008;3(7):1125-31.

12. Peram M. R, Jalalpure S, Kumbar V, Patil S, Joshi $\mathrm{S}$, Bhat K, Diwan P. Factorial design based curcumin ethosomal nanocarriers for the skin cancer delivery: in vitro evaluation. J Liposome Res. 2019;29(3):291-311.

13. Kulhari H, Pooja D, Shrivastava S, Kuncha M, Naidu V. G. M., Bansal V, Sistla R, Adams DJ. Trastuzumab-grafted PAMAM dendrimers for the selective delivery of anticancer drugs to HER2positive breast cancer. Sci Rep. 2016;6:23179.

14. Banerjee S, Panda C. K, Das S. Clove (Syzygium aromaticum L.), a potential chemopreventive agent for lung cancer. Carcinogenesis. 2006;27(8):1645-54.

15. Duke J. A, du Cellier J. L (1993). CRC Handbook of Alternative Cash Crops, CRC Press, Lond. 1 ${ }^{\text {st }}$ Edition. PP 536. ISBN 9780849336201

16. Zheng G. Q, Kenney P. M, Lam L. K. Sesquiterpenes from clove (Eugenia caryophyllata) as potential anticarcinogenic agents. J Nat Prod. 1992;55(7):999-1003.

17. Scott E. N, Gescher A. J, Steward W. P, Brown K. Development of dietary phytochemical chemopreventive agents: biomarkers and choice of dose for early clinical trials. Cancer Prev Res (Phila). 2009 Jun;2(6):525-30.

18. Montes-Belmont R, Carvajal M. Control of Aspergillus flavus in maize with plant essential oils and their components. J Food Prot. 1998;61(5):616-9.

19. Shiraki K, Yukawa T, Kurokawa M, Kageyama S. [Cytomegalovirus infection and its possible treatment with herbal medicines]. Nihon Rinsho. 1998;56(1):156-60.
20. Dwivedi V, Shrivastava R, Hussain S, Ganguly C, Bharadwa M. Comparative Anticancer Potential of Clove (Syzygium aromaticum) - An Indian Spice Against Cancer Cell Lines of Various Anatomical Origin. J Asian Pacific Journal of Cancer Prevention. 1989;12: 2011

21. Pfeffer C. M, Singh A. T. K. Apoptosis: A Target for Anticancer Therapy. Int J Mol Sci. $2018 ; 19(2): 448$.

22. Pisano M, Pagnan G, Loi M, Mura M. E, Tilocca M. G, Palmieri G, Fabbri D, Dettori MA, Delogu G, Ponzoni M, Rozzo C. Antiproliferative and proapoptotic activity of eugenol-related biphenyls on malignant melanoma cells. Mol Cancer. 2007; 18;6-8.

23. Bhat S.S, Revankar V.K, Kumbar V, Bhat K, Kawade V.A. Synthesis, crystal structure and biological properties of a cis-dichloridobis (diimine) copper(II) complex. Acta Crystallogr C Struct Chem. 2018;1(74)(Pt 2):146-151.

24. Das A, Jayaprakash B. Evaluation of Therapeutic Potential of Eugenol-A Natural Derivative of Syzygium aromaticum on Cervical Cancer. Asian Pac J Cancer Prev. 2018;19(7):1977-1985.

25. Nirmala M.J, Durai L, Gopakumar V, Nagarajan R. Anticancer and antibacterial effects of a clove bud essential oil-based nanoscale emulsion system. Int $\mathbf{J}$ Nanomedicine. 2019;14:6439-6450.

26. Firdos A. K, Sultan A, Dana A, Munthar A, Sarah A. A. Extracts of Clove (Syzygium aromaticum) Potentiate FMSP-Nanoparticles Induced Cell Death in MCF-7 Cells. International Journal of Biomaterials, vol. 2018, ArticleID 8479439, 10 pag es, 2018.

27. Faisal N. A, Rini P, Mochamat G. W, Eko B. H. Yield, Quality, and Antioxidant Activity of Clove (Syzygium aromaticum L.) Bud Oil at the Different Phenological Stages in Young and Mature Trees. Scientifica, vol. 2020, ArticleID 9701701, 8 pages, 2020.

28. Bakour. M, Soulo N, Hammas, N, Fatemi H.E, Aboulghazi A, Taroq A, Abdellaoui A, Al-Waili N, Lyoussi B. The Antioxidant Content and Protective Effect of Argan Oil and Syzygium aromaticum Essential Oil in Hydrogen PeroxideInduced Biochemical and Histological Changes. Int. J. Mol. Sci. 2018;19:610.

29. Silvestri J. D. F, Paroul N, Czyewski E, Lerin L, Rotava I, Cansian R. L, Mossi A, Toniazzo G, Oliveira D, de Treichel H, Perfil D. Chemical composition and antioxidant and antibacterial activities of clove essential oil (Eugenia caryophyllata Thunb). Rev. Ceres 2010;57 (5):589594.

30. Sebaaly C, Helene G. G, Serge S. Effect of composition, hydrogenation of phospholipids and lyophilization on the characteristics of eugenolloaded liposomes prepared by ethanol injection method. Food Bioscience. 2016;15:1-10

31. Cortés-Rojas D.F, de Souza C.R, Oliveira W.P. Clove (Syzygium aromaticum): A precious spice. Asian Pac J Trop Biomed. 2014 ;4(2):90-6. 


\section{Acknowledgement}

We thank all the members of Advance research wing of Rajiv Gandhi University of Health Sciences, Bengaluru for funding the project. The fund sponsored by the university is partly used for this project. We also thank Principal Dr Ramakant Nayak, Maratha Mandal's NGH Institute of Dental Sciences, for his constant support and encouragement.

\section{Tables and Graphs}

FRAP: GRAGH 1

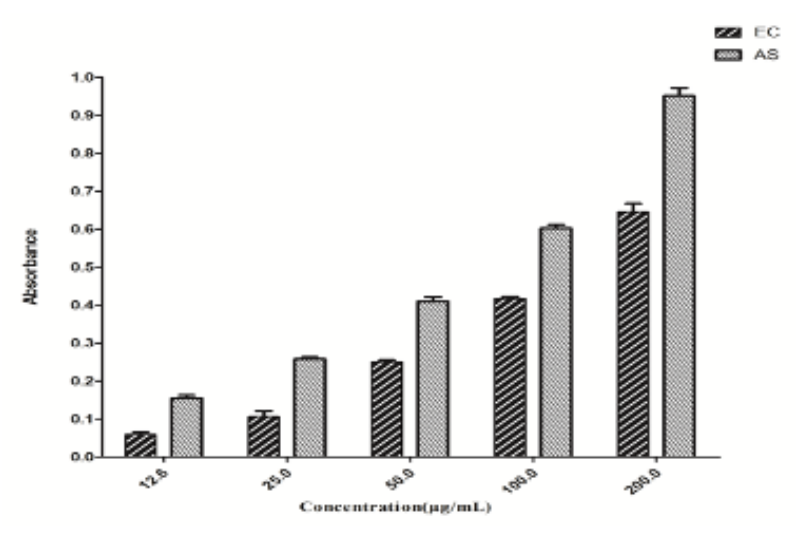

PM Assay: GRAPH 2

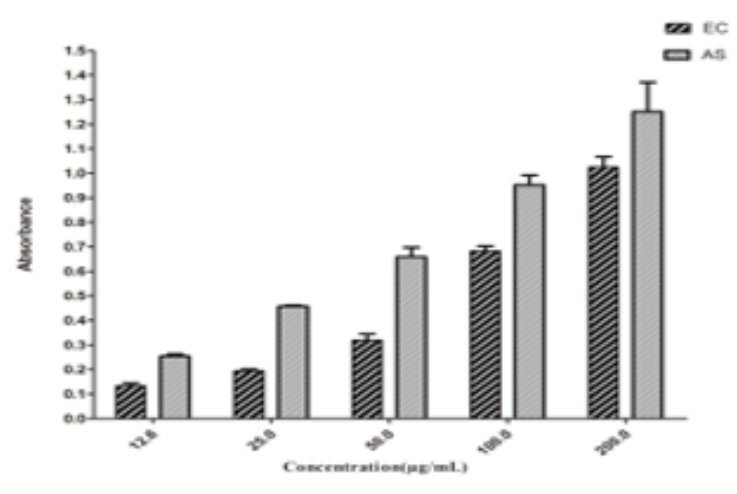

Table 1a: $\mathrm{IC}_{50}$ value of compounds in $\mu \mathrm{g} / \mathrm{ml}$ (MTT assay)

Compound

Ethanolic extract of Clove

Cisplatin
KB

224.3

27.85
L292

607.8

61.63

Table $1 \mathrm{~b}: \mathrm{IC}_{50}$ value of compounds in $\mu \mathrm{g} / \mathrm{ml}$ (Neutral Red assay )

\begin{tabular}{|l} 
Compound \\
\hline Ethanolic extract of Clove
\end{tabular}

Cisplatin
KB

252.6

39.48
L292

486.0

123.9

Table 2: Table Showing Mean value at various concentration of Ethnolic extract (EE) of clove for FRAP assay comparing with standard Ascorbic acid

\begin{tabular}{|c|c|c|c|c|c|c|}
\hline \multirow{2}{*}{ Concentration } & \multicolumn{2}{|c|}{ EE of Clove } & \multirow{2}{*}{$\begin{array}{c}\text { EE of clove } \\
\text { Mean }\end{array}$} & \multicolumn{2}{|c|}{$\begin{array}{c}\text { Ascorbic } \\
\text { acid }\end{array}$} & \multirow{2}{*}{$\begin{array}{l}\text { Ascorbic acid } \\
\text { Mean }\end{array}$} \\
\hline & 1 & 2 & & 1 & 2 & \\
\hline 200.0 & 0.623 & 0.668 & 0.645 & 0.932 & 0.971 & 0.9515 \\
\hline 100.0 & 0.412 & 0.423 & 0.417 & 0.593 & 0.612 & 0.602 \\
\hline $\mathbf{5 0 . 0}$ & 0.256 & 0.245 & 0.250 & 0.398 & 0.421 & 0.409 \\
\hline 25.0 & 0.092 & 0.121 & 0.1065 & 0.263 & 0.253 & 0.258 \\
\hline 12.6 & 0.053 & 0.065 & 0.059 & 0.163 & 0.145 & 0.154 \\
\hline
\end{tabular}

Table 3: Showing Mean value at various concentration of $E E$ of clove for $P M$ assay comparing with standard Ascorbic acid

\begin{tabular}{|c|c|c|c|c|c|c|}
\hline \multirow{2}{*}{ Concentration } & \multicolumn{2}{|c|}{ EE of Clove } & \multirow{2}{*}{ EE of clove Mean } & \multicolumn{2}{c|}{ Ascorbic acid } & Ascorbic acid Mean \\
\cline { 2 - 6 } & $\mathbf{1}$ & $\mathbf{2}$ & & $\mathbf{1}$ & $\mathbf{2}$ & 1.251 \\
\hline $\mathbf{2 0 0 . 0}$ & 0.982 & 1.068 & 1.025 & 1.132 & 1.371 & 0.952 \\
\hline $\mathbf{1 0 0 . 0}$ & 0.665 & 0.703 & 0.682 & 0.993 & 0.912 & 0.659 \\
\hline $\mathbf{5 0 . 0}$ & 0.295 & 0.345 & 0.32 & 0.698 & 0.621 & 0.458 \\
\hline $\mathbf{2 5 . 0}$ & 0.188 & 0.201 & 0.194 & 0.463 & 0.453 & 0.254 \\
\hline $\mathbf{1 2 . 6}$ & 0.122 & 0.145 & 0.133 & 0.263 & 0.245 & \\
\hline
\end{tabular}


Table 4: Showing Mean value at various concentration of EE of clove for DPPH assay comparing with standard Ascorbic acid

\begin{tabular}{|c|c|c|c|c|c|c|c|c|}
\hline \multirow{2}{*}{ Concentration } & \multicolumn{2}{|c|}{ EE of Clove } & \multirow{2}{*}{ EE of clove Mean } & \multirow{2}{*}{ SD } & \multicolumn{2}{|c|}{ Ascorbic acid } & \multirow[t]{2}{*}{ Ascorbic acid Mean } & \multirow[t]{2}{*}{ SD } \\
\hline & 1 & 2 & & & 1 & 2 & & \\
\hline 12.5 & 32.55 & 29.72 & 31.14 & 2.55 & 11.34 & 14.94 & 13.14 & 11.12 \\
\hline 25 & 48.74 & 45.92 & 47.33 & 5.08 & 28.74 & 35.92 & 32.33 & 14.58 \\
\hline 50 & 62.56 & 69.33 & 65.95 & 1.96 & 52.56 & 55.33 & 53.95 & 21.14 \\
\hline 100 & 79.92 & 75.80 & 77.86 & 2.04 & 69.92 & 72.8 & 71.36 & 28.56 \\
\hline 200 & 89.33 & 85.80 & 87.57 & 1.79 & 85.33 & 82.8 & 84.07 & 53.47 \\
\hline
\end{tabular}

5a: Showing cell viability value at various concentration of $E E$ of clove for MTT assay comparing with standard drug Cisplatin for KB cell lines

\begin{tabular}{|c|c|c|c|c|c|c|c|c|}
\hline & \multicolumn{7}{c|}{ Cell Viability(KB) MTT } \\
Concentration $(\boldsymbol{\mu g} / \mathbf{m l})$ & \multicolumn{3}{|c|}{ EE of clove } & EE of clove Mean & \multicolumn{3}{c|}{ Cisplatin } & Cisplatin Mean \\
\hline $\mathbf{0}$ & 100.00 & 96.12 & 103.88 & 100 & 107.45 & 93.88 & 98.67 & 100 \\
\hline $\mathbf{2 5}$ & 93.12 & 96.96 & 98.99 & 96.35 & 21.17 & 22.25 & 25.22 & 22.88 \\
\hline $\mathbf{5 0}$ & 89.50 & 96.33 & 92.92 & 92.91 & 15.01 & 18.29 & 15.45 & 16.25 \\
\hline $\mathbf{1 0 0}$ & 76.75 & 80.77 & 83.78 & 80.43 & 12.83 & 10.45 & 14.90 & 12.72 \\
\hline $\mathbf{2 0 0}$ & 59.74 & 66.17 & 62.75 & 62.88 & 7.58 & 11.55 & 8.42 & 9.18 \\
\hline $\mathbf{4 0 0}$ & 39.68 & 40.89 & 43.73 & 41.43 & 4.42 & 5.54 & 7.68 & 5.88 \\
\hline $\mathbf{8 0 0}$ & 21.86 & 25.71 & 25.91 & 24.49 & 2.39 & 4.52 & 3.10 & 3.33 \\
\hline $\mathbf{I C}-50$ & & 224.3 & & & & 2.785 & & \\
\hline
\end{tabular}

Table 5b: Showing cell viability value at various concentration of EE of Clove for MTT assay comparing with standard drug Cisplatin for L929 cell lines

\begin{tabular}{|c|c|c|c|c|c|c|c|c|}
\hline & \multicolumn{9}{|c|}{ Cell Viability(L929) MTT } \\
\hline Concentration $(\boldsymbol{\mu g} / \mathbf{m l})$ & \multicolumn{3}{|c|}{ EE of clove } & EE of clove Mean & \multicolumn{3}{c|}{ Cisplatin } & Cisplatin Mean \\
\hline $\mathbf{0}$ & 99.55 & 97.46 & 102.99 & 100 & 104.74 & 95.88 & 99.3 & 99.97 \\
\hline $\mathbf{2 5}$ & 96.69 & 100.76 & 98.46 & 98.6367 & 38.33 & 35.89 & 37.79 & 36.84 \\
\hline $\mathbf{5 0}$ & 94.61 & 97 & 92.974 & 94.8613 & 32.30 & 30.08 & 34.11 & 32.16333 \\
\hline $\mathbf{1 0 0}$ & 83.46 & 85.69 & 89.07 & 86.0733 & 31.73 & 25.58 & 28.73 & 28.68 \\
\hline $\mathbf{2 0 0}$ & 68.15 & 71.53 & 74.15 & 71.2767 & 19.52 & 22.64 & 26.29 & 22.81667 \\
\hline $\mathbf{4 0 0}$ & 58.69 & 63.46 & 65.30 & 62.4833 & 18.97 & 15.5 & 17.71 & 17.39333 \\
\hline $\mathbf{8 0 0}$ & 43.69 & 46.84 & 40.25 & 43.5933 & 12.69 & 14.89 & 8.47 & 12.01667 \\
\hline $\mathbf{I C - 5 0}$ & & 607.8 & & & & 6.476 & & \\
\hline
\end{tabular}

Table 6a: Showing cell viability value at various concentration of EE of Clove for Neutral red assay comparing with standard drug Cisplatin for KB cell lines

\begin{tabular}{|c|c|c|c|c|c|c|c|c|}
\hline & \multicolumn{7}{|c|}{ Cell Viability(KB) NR } \\
\hline Concentration $(\mathbf{\mu g} / \mathbf{m l})$ & \multicolumn{3}{|c|}{ EE of clove } & EE of Clove Mean & \multicolumn{3}{c|}{ Cisplatin } & Cisplatin Mean \\
\hline $\mathbf{0}$ & 101.00 & 97.32 & 101.68 & 100 & 105.45 & 94.88 & 99.67 & 100 \\
\hline $\mathbf{2 5}$ & 97.85 & 101.23 & 94.15 & 97.7433 & 29.33 & 27.90 & 32.80 & 30.01 \\
\hline $\mathbf{5 0}$ & 88.72 & 92.28 & 86.69 & 89.23 & 21.30 & 23.09 & 25.12 & 23.17 \\
\hline $\mathbf{1 0 0}$ & 76.46 & 79.69 & 83.54 & 79.8967 & 19.70 & 15.90 & 16.48 & 17.36 \\
\hline $\mathbf{2 0 0}$ & 50.15 & 53.39 & 55.08 & 52.8733 & 13.74 & 12.58 & 15.74 & 14.02 \\
\hline $\mathbf{4 0 0}$ & 40.69 & 43.08 & 47.15 & 43.64 & 12.00 & 11.56 & 9.29 & 10.95 \\
\hline $\mathbf{8 0 0}$ & 33.08 & 36.46 & 37.13 & 35.5567 & 5.97 & 7.55 & 8.71 & 7.41 \\
\hline $\mathbf{I C - 5 0}$ & & 252.6 & & & & 3.98 & & \\
\hline
\end{tabular}


Sheethal Sanikop et.al., Anticancer activity of Clove on KB cell lines

Table 6b: Showing cell viability value at various concentration of EE of clove for Neutral red assay comparing with standard drug Cisplatin for L929 cell lines

\begin{tabular}{|c|c|c|c|c|c|c|c|c|}
\hline & \multicolumn{9}{|c|}{ Cell Viability(L929) NR } \\
\hline Concentration $(\boldsymbol{\mu g} / \mathbf{m l})$ & \multicolumn{3}{|c|}{ EE of clove } & EE of clove Mean & \multicolumn{3}{|c|}{ Cisplatin } & Cisplatin Mean \\
\hline $\mathbf{0}$ & 98.72 & 97.12 & 104.15 & 100 & 102.84 & 95.98 & 101.17 & 100 \\
\hline $\mathbf{2 5}$ & 94.34 & 97.74 & 99.36 & 97.15 & 39.55 & 40.42 & 43.17 & 41.04 \\
\hline $\mathbf{5 0}$ & 90.46 & 95.32 & 93.92 & 93.23 & 33.29 & 31.44 & 30.01 & 31.58 \\
\hline $\mathbf{1 0 0}$ & 86.73 & 81.73 & 79.13 & 82.53 & 21.44 & 26.89 & 27.82 & 25.39 \\
\hline $\mathbf{2 0 0}$ & 56.90 & 59.31 & 63.53 & 59.91 & 20.55 & 19.42 & 13.58 & 17.85 \\
\hline $\mathbf{4 0 0}$ & 51.55 & 58.42 & 55.58 & 55.18 & 14.39 & 17.68 & 12.42 & 14.83 \\
\hline $\mathbf{8 0 0}$ & 44.22 & 42.53 & 40.22 & 42.32 & 6.52 & 8.10 & 10.39 \\
\hline $\mathbf{I C - 5 0}$ & & 486 & & & & 12.66 & 8.33 \\
\end{tabular}

\section{Legends for figures}

Figure 1: Photomicrograph showing Live and dead cell assay of KB cells using AO and EB double staining.

Untreated control cells (A-10X), cells treated with Syzygium aromaticum for $48 \mathrm{~h}$. The live cells demonstrated green fluorescence and dead cells exhibited dark-orange red fluorescence. Untreated cells are shown as controls (B,C-10X).
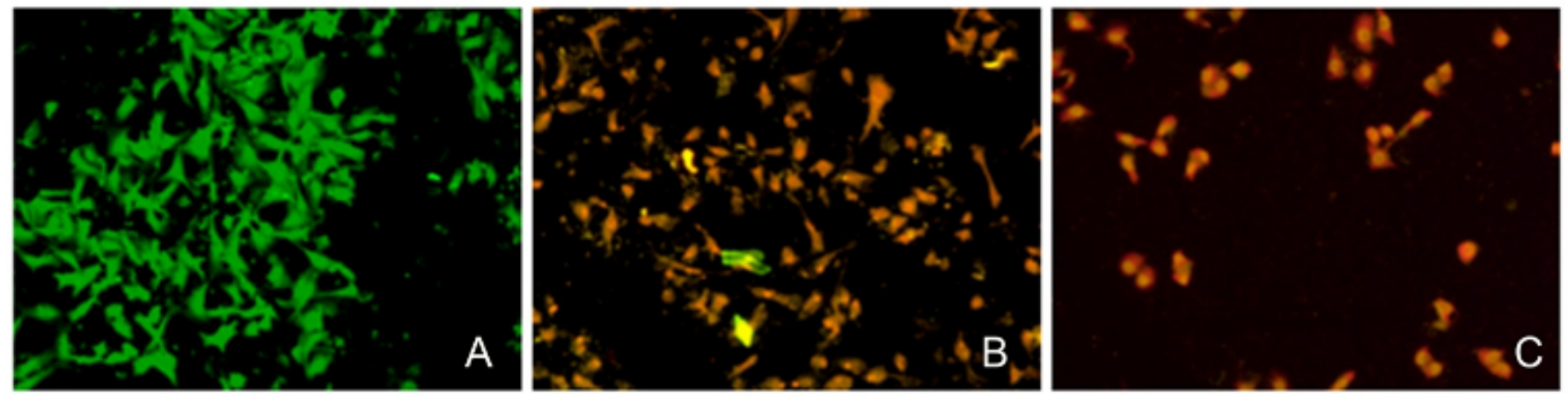

Figure 2: Photomicrograph showing Apoptotic nuclear changes observed in KB cells by DAPI staining.

Untreated control cells (A). cells treated with Clove extract for 48 h. Untreated cells are shown as controls. Arrows represent chromatin condensation and nuclear shrinkage, circles represent nuclear blebbing, circles with arrows denote nuclear fragmentation and square represents apoptotic bodies. (B-40X, C-100X).
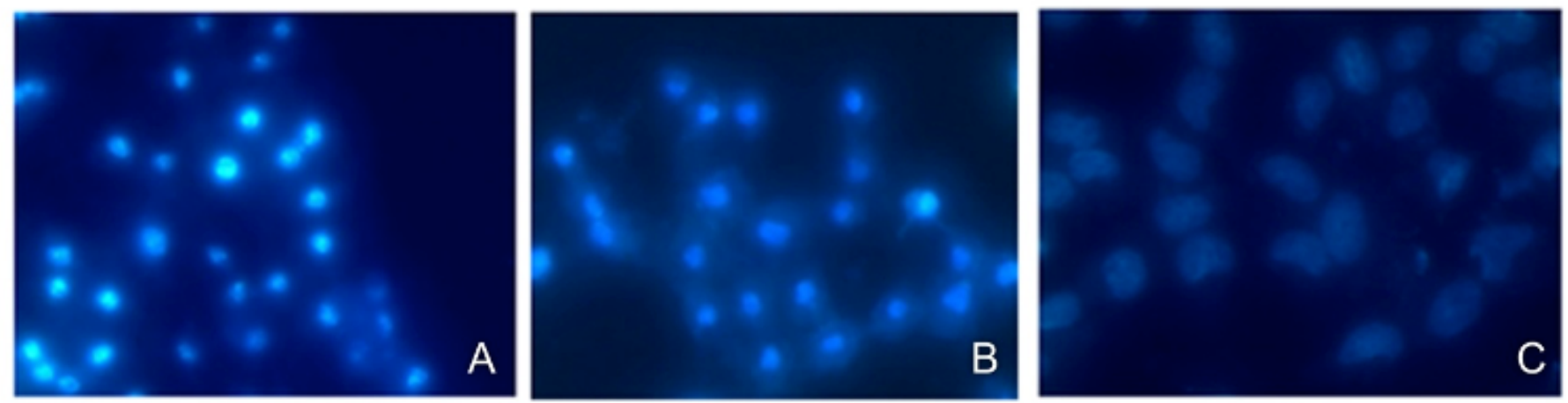